\title{
Comparative study of anthropometric measurement and body composition between basketball players from different competitive levels: elite and sub-elite
}

\author{
Masanovic B. ${ }^{\mathrm{ABCDE}}$, Popovic S. ${ }^{\mathrm{ABCD}}$, Bjelica D. ${ }^{\mathrm{ABDE}}$ \\ Faculty for Sport and Physical Education, University of Montenegro, Montenegro
}

Authors' contribution: A - Study design; B - Data collection; C - Statistical analysis; D - Manuscript Preparation; E - Funds collection.

\begin{abstract}
Purpose:

The purpose of this study was to describe anthropometric characteristics and body composition of basketball players from two competitive levels, elite and sub-elite as well as to make a comparison between them.

Material: $\quad$ Fifty-seven male subjects were enrolled in this study, divided into three groups: fourteen elite basketball players, twelve sub-elite basketball players and thirty-one healthy sedentary subjects (subjects from general population). All subjects were assessed for anthropometric measures required for the calculation of body composition variables, using standardized procedures recommended by previous studies. Data was analyzed using SPSS and the descriptive statistics were expressed as a mean (SD) for each variable, while the ANOVA and the LSD Post Hoc tests were carried out to detect effects of each type of sport.

Results: $\quad$ The results showed that a significant difference was found in variables height, weight, muscle mass, bone content and body fat, while a significant difference was not found for the remaining variable, body mass index.

Conclusions: $\quad$ Therefore, these findings may give coaches from the region better working knowledge and thus provide knowledges for basketball experts which will help them to select talented players as best as possible.

Keywords: morphological characteristics, body composition, male athletes, senior
\end{abstract}

\section{Introduction}

Throughout its history, basketball has evolved from an alternative game to a highly selective sport branch where success is reserved exclusively for the most talented and most capable individuals [1]. At the initial stage of its appearance, it was intended and accessible to a wide range of interested parties, leading to incredibly rapid expansion and popularity [2]. In the United States, the cradle of basketball, over 26 million Americans play basketball today [3], of which 15.5 million people play casual/pickup basketball, 4.1 million playing in organized leagues, and 5.8 million play on a school or college team. A quarter of this large number of basketball participants are female, while nearly half are under the age of 18 . In contrast to the USA, where basketball is by far the most popular sport by the number of involved players, basketball is not a number one sport in Serbia. However, at the biggest world competitions, Serbia is at the winning podium immediately behind the US, and the official data of the International Basketball Federation (FIBA) shows that Serbia is the biggest exporter of national players in the world, and exports $81.8 \%$ of national players. It is also interesting to add that, according to official data, since the establishment of the men's professional basketball league in the North America (National Basketball Association NBA), in this competition the most foreign players came exactly from Serbia. The mentioned results are a product of professional and studious work, and in order to keep Serbia at the top of the world basketball, in the future, it has necessary to constantly explored and searched for

(c) Masanovic B., Popovic S., Bjelica D., 2019

doi:10.15561/18189172.2019.0403 new knowledge. Experts facilitates work the availability of knowledge from various scientific disciplines, but there are aggravating circumstances in the following facts: today's athlete brought to a high level of preparedness, the results in certain disciplines are so impressive that the question is whether higher ranges are possible, at the biggest sporting events, there are a large number of almost equalized athletes, so the nuances between qualitative and top players decide who will take the victory [4]. Nevertheless, the desires and motives of all participants are not equal, so basketball at recreational level and at the level of the amateur league is reflected in the free choice, the massiveness of the receptionists and the widespread distribution [5], while the top basketball can be defined as a game aimed at achieving the greatest sporting achievements, whose basic metering unit of success is precisely the sporting result [6].

The focus on the greatest sporting results depends to a large extent on the timely selection of players [7], so in elite clubs the experts are constantly looking for the most effective formula for recognizing talented young players, because their goal is to find just the players who are by their characteristics the most similar to the elite players [8]. To accomplish this goal, they must be prepared for long-lasting and studious work, because different factors may predispose individuals towards a successful career, and identifying characteristics that give priority to players can be very difficult [9]. Some of the answers to this problem can be found by comparing the anthropometric characteristics and the body composition of elite players and lower ranked players $[10,11]$. Many previous studies prove that anthropometric characteristics and body 
composition significantly contribute to sporting success $[12,13,14]$. It is widely known that each sport has its own specific requirements, and that the body is required to work at optimal capacity in terms of biomechanics and physiology [15]. Therefore, it is more than logical to expect from top athletes to have anthropometric characteristics and body composition adapted to the functional requirements of the related sport, because they, among other factors, contribute to the optimal routine of exercise and performance [16]. In other words, body weight can affect speed, endurance and strength, while body composition can affect strength and agility [17], and for successful participation in basketball games of the elite rank of competition, in addition to a higher level of technical and tactical skills, each athlete is also required to have appropriate anthropometric characteristics and body composition [18]. Comparisons between players exposed to systematic training with already highly selected players can help to establish the distinguishing features of expertise and to identify the factors that determine a player's potential to progress to higher levels of play [19].

The purpose of this study was to describe the anthropometric characteristics and the body composition of the basketball players of different levels of competition, to examine the differences between elite and sub-elite competitive levels, thus providing the basketball experts with specific knowledge that will help them to select talented players as best as possible.

\section{Material and Method}

Participants: Fifty-seven male subjects were enrolled in this study. They were divided into three groups: fourteen elite basketball players $(23.50 \pm 2.77$ yrs.) from the Serbian Premier League, twelve sub-elite basketball players $(25.08 \pm 3.18$ yrs.) from the Fifth Serbian League and thirty-one healthy sedentary subjects from the same country (24.94 \pm 3.10 yrs.). The measurements were carried out in the winter preparation period.

Procedure: All subjects were clinically healthy and had no recent history of infectious disease, asthma or cardio-respiratory disorders. All of them gave their written consent and the local ethics committee approved the protocol of the study. All subjects were assessed for the twenty anthropometric measures required for the calculation of body composition variables, using the standardized procedure recommended by the International Biological Program (IBP) standards respecting the basic rules and principles related to the parameter choice, standard conditions and measurement techniques, as well as the standard measuring instruments adjusted before measurement was carried out. Height and weight were measured in the laboratory with the subject dressed in light clothing. Height was measured to the nearest $0.1 \mathrm{~cm}$ using a fixed stadiometer, and weight was measured to the nearest $0.1 \mathrm{~kg}$ with a standard scale utilizing a portable balance. Skinfolds $(\mathrm{mm})$ were measured at six sites: triceps skinfold thickness, forearm skinfold thickness, thigh skinfold thickness, calf skinfold thickness, chest skinfold thickness and abdominal skinfold thickness (using a skinfold caliper). The circumferences $(\mathrm{cm})$ were measured at eight sites: minimum and maximum circumference of the upper arm, minimum and maximum circumference of the forearm, minimum and maximum circumference of the upper leg, minimum and maximum circumference of the lower leg (using a anthropometric tape). At last the following diameters were measured to the nearest $0.1 \mathrm{~cm}$ : elbow diameter, wrist diameter, diameter of the knee, diameter of the ankle (using a small siding caliper). To reduce measurement variation, the same investigator examined all of the subjects. Body mass index (BMI) was calculated as body mass in kilograms divided by height in meters squared $(\mathrm{kg} / \mathrm{m} 2)$. The values of bone, muscular, and fat contents of body composition were acquired by distributing all the measured variables in formulas by Mateigka [20].

Statistical analysis: The data obtained in the research was processed using the application statistics program SPSS 20.0, adjusted for use on personal computers. The descriptive statistics were expressed as a mean (SD) for each variable. Analysis of the variance (ANOVA) and the LSD Post Hoc test were carried out to detect the effects for each level of competition (elite or sub-elite) on each variable: body height, body weight, body mass index (BMI), and muscle, bone and fat content of the body, as well as to control it by sedentary subjects. The significance was set at an alpha level of 0.05 .

Table 1. Descriptive data and ANOVA of male athletes enrolled in the study $(n=57)$

\begin{tabular}{lllll}
\hline Variables & $\begin{array}{l}\text { Elite Basketball } \\
(\mathbf{n}=14)\end{array}$ & $\begin{array}{l}\text { Sub-Elite Basketball } \\
(\mathbf{n = 1 2 )} \\
\text { Mean } \pm \text { Standard Deviation }\end{array}$ & Control $(\mathbf{n = 3 1 )}$ & ANOVA \\
\hline Height (cm) & $199.50 \pm 7.37$ & $192.49 \pm 4.64$ & $183.72 \pm 7.60$ & $0.000^{*}$ \\
Weight (kg) & $99.57 \pm 11.60$ & $90.63 \pm 14.45$ & $86.74 \pm 14.68$ & $0.022^{*}$ \\
BMl (kg/m2) & $24.94 \pm 1.40$ & $24.48 \pm 3.87$ & $25.61 \pm 3.49$ & $0.550^{\wedge}$ \\
Muscle mass (\%) & $51.26 \pm 1.99$ & $48.38 \pm 3.55$ & $48.32 \pm 3.27$ & $0.022^{*}$ \\
Bone content (\%) & $16.21 \pm 0.77$ & $15.93 \pm 2.36$ & $14.78 \pm 1.78$ & $0.024^{*}$ \\
Body fat (\%) & $11.54 \pm 1.97$ & $16.38 \pm 6.82$ & $18.51 \pm 5.89$ & $0.001^{*}$ \\
\hline
\end{tabular}

Note: $\mathrm{N}$ - number of subjects; BMI - body mass index; ${ }^{\wedge}$ - non-significant; ${ }^{*}$ - significant difference between groups. 


\section{Results}

Anthropometric characteristics of subjects are shown in Table 1. There were significant differences in five out of six variables among the groups. Hence, a significant difference was found for height $(\mathrm{F}=25.67)$, weight $(\mathrm{F}=$ $4.08)$, muscle mass $(\mathrm{F}=4.78)$, bone content $(\mathrm{F}=4.02)$ and body fat $(\mathrm{F}=7.89)$. There is no significant difference for the remaining variable: body mass index $(\mathrm{F}=0.60)$.

Significant differences of anthropometric characteristics among particular sports are shown in Figure 1. The LSD Post Hoc test indicated that elite basketball players were taller and heavier than sub-elite basketball players or subjects from the control group, while subject of control group have lowest value for both mentioned variables. Also, elite basketball players had the highest percentage of muscle mass and bone content, while subjects from the control group had the lowest values for both mentioned variables. On the contrary, elite basketball players had the lowest percentage of body fat, while subjects from the control group had the most body
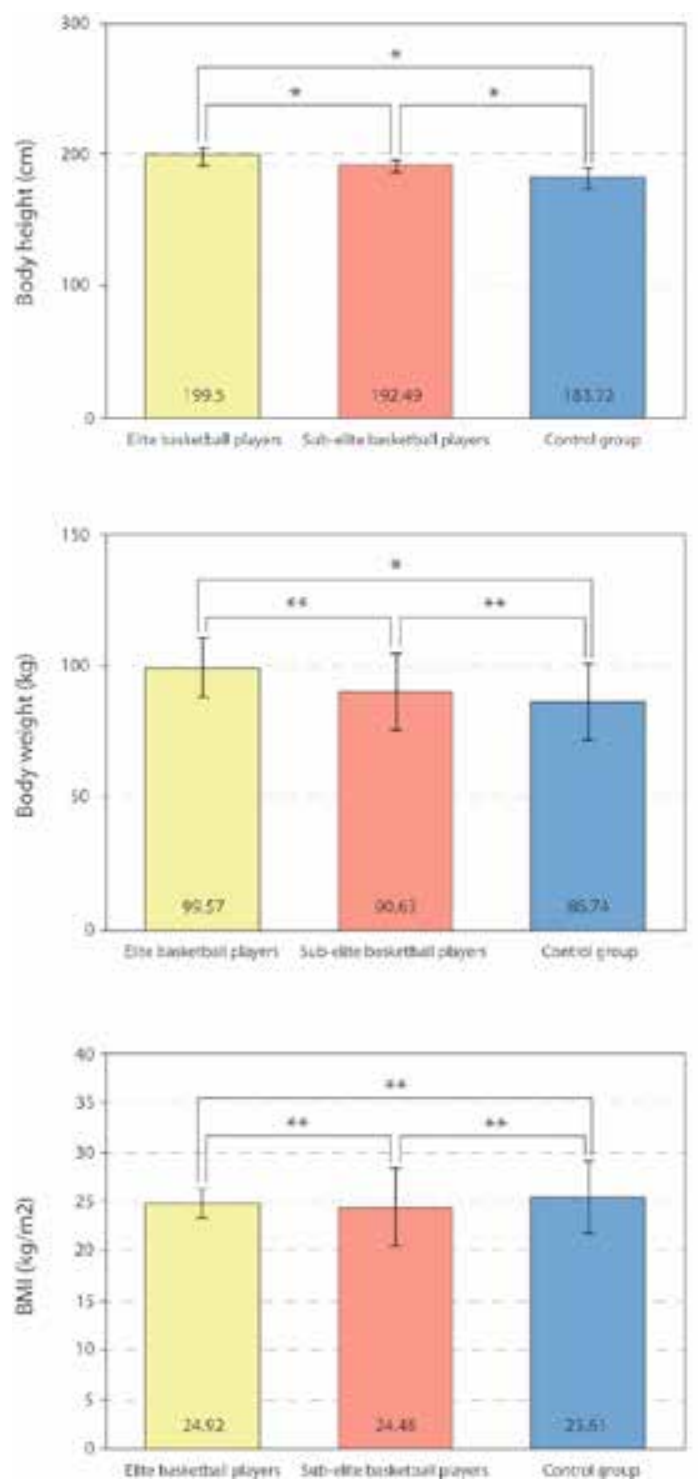

Legend: * - significance; **-non-significance. fat. There is no significant difference when it comes to body mass index, but it was noticed that subjects from the control group had the highest values, while sub-elite basketball players had the lowest values.

\section{Discussion}

Results of this study support previous investigations indicating a strong difference regarding body height among basketball players and subjects from the control group that represents general population [21, 22, 23]. The reason for the growth tendencies of basketball players is because the game requires that they handle the ball above the head [7], and their height helps them to easily reach the hoop and perform the tasks of defence and attack. Taller basketball players have an advantage because the ball has to pass a short distance from hand to basket. Also, it provides them with the ability to jump higher than their opponents, gives them an opportunity to easier block their shoots, and also makes it difficult for the opponent to execute the blockade. A significant difference
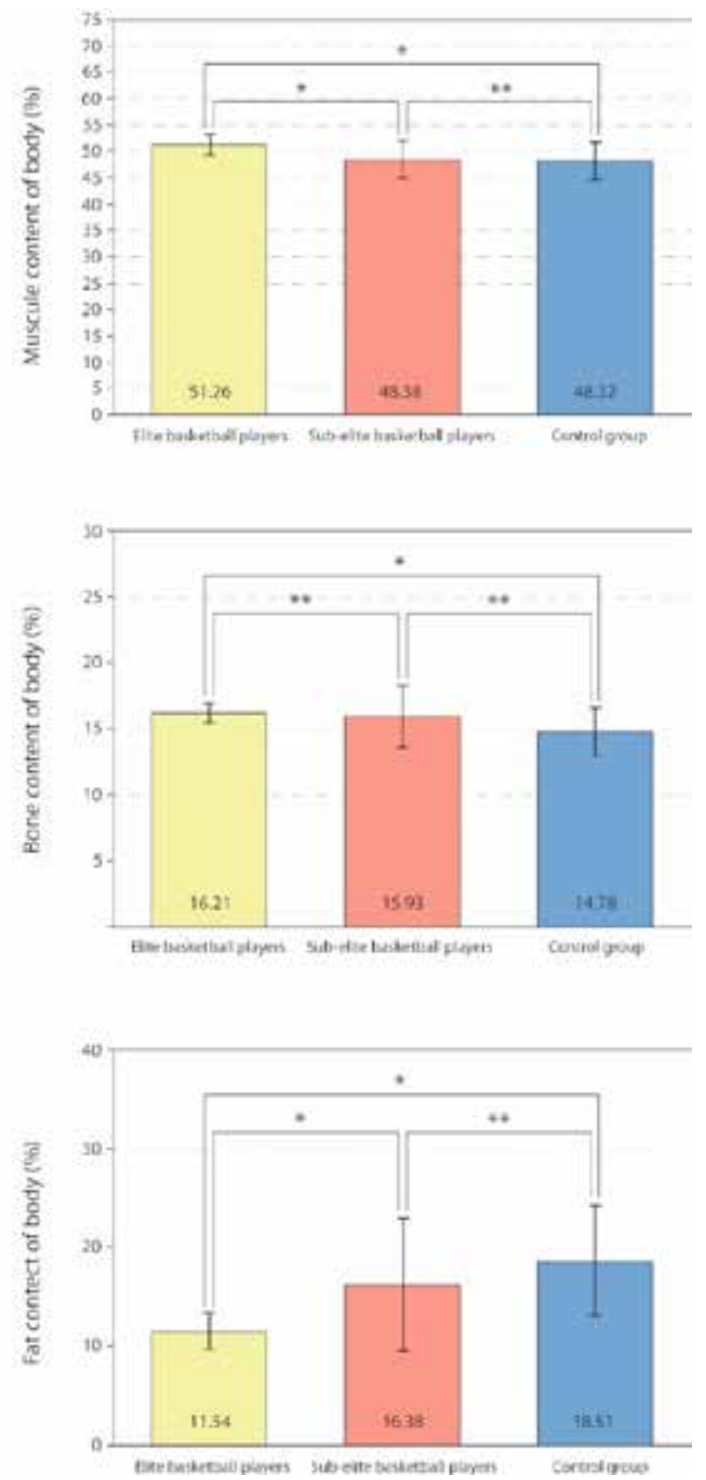

Figure 1. LSD Post Hoc test for the different parameters among the subjects 
in body height in favor of elite basketball players is also not surprising, since similar results can also be found in numerous previous studies $[5,24]$. This proves that there is a tendency for the tallest children to be recruited in basketball, and consequently, the selection criteria are very important. However, extra talented short players, especially those with a high vertical jump, will also be selected and can play a significant role in basketball, however, the fact is that male professional players, even the shortest, are usually above average in height compared to the general population [8]. If we compare the elite players involved in this study with players of the world's finest selections, we will notice very small differences. According to official statistics, the average height of all participants in the FIBA Basketball World Cup that was played in Spain in 2014 was 199.04 centimeters. When we add that the average body height of the national teams of USA and Slovenia (winner from the last World and European Basketball Championship) was 201 centimeters and 200.08 centimeters, we can conclude that the elite basketball players included in this study were tall enough $(199.5 \mathrm{~cm})$ and did not lag behind the top World players, and that the selection of players was done well, which is not a surprise since this area is part of the Dinaric Alps, which are known for high percentage of very tall subjects $[25,26]$.

However, we found that that basketball players from both groups were heavier (elite players significantly, subelite players slightly) than the subjects from the control group, mostly due to the reason they are significantly taller than they are. Of course, it was expected that the reason for that can be supported with the fact that the average size of the basketball players has increased significantly in the last thirty years [21]. The reason for this can be better nutrition, also the use of nutritional supplements especially in professional basketball leagues. It is important to note that neither in the body weight the elite players from this study $(99.57 \mathrm{~kg}$ ) do not lag behind the players of the aforementioned selections of the USA $(102.82 \mathrm{~kg})$ and Slovenia $(97.03 \mathrm{~kg})$, which also adds to the benefit of their quality.

We found that subjects from the control group have the highest values of the body mass index, while the lowest values have the sub-elite basketball players. The difference between the groups is not significant. BMI of subjects from general population is higher because their physical activity is far lower than the activity of basketball players from both groups. On the other hand, the BMI of elite players is higher than in sub-elite players because the body of the elite players must be stronger because of the higher demands of their rankings [27, 5]. The BMI values of the aforementioned teams of USA and Slovenia are 25.34 and 24.22 , so we conclude that this parameter of elite players (24.94) and sub-elite players (24.48) from this study show their high level of quality.

The highest value of muscle mass of elite basketball players, which is significantly higher than the other two groups of respondents, is expected, because increasing muscle mass is important to improve strength and power, which contribute to sports performance [28]. Accordingly, the absence of a difference between sub-elite basketball players and subjects from the control group surprising as. However, the muscle mass of sub-elite players from this study corresponds to the values obtained from previous studies [29], based on which we conclude that subjects from the control group are physically active enough and lead a quality way of life.

Accordingly, the percentage of bone content of elite basketball players is of highest values, slightly higher compared to sub-elite basketball players, and significantly higher compared to subjects from the control group, which supports the previous knowledge of the positive impact of physical activity on bone mass [30,31].

Lastly, a low percentage of body fat of elite basketball players from this study, which was significantly lower than the percentage of body fat of sub-elite basketball players and subjects from the control group, showed that elite players have a high level of physical performance. On the contrary, sub-elite basketball players had slightly lower percentage of body fat than subjects from the control group, which again implies of the existence of a difference in the way of training between teams of different competitive levels. Excessive fat mass compromises physical performance [32], and with the increase in sports progression, the percentage of fat tissue decreases [33, 34]. Of course, it is very important to remember that the National Strength and Conditioning Association indicates that body fat percentages should not be lowered below 7 percent, because basketball players need a certain body fat percentage to perform well enough and achieve their full playing potential.

The importance of a body composition is great when determining elite basketball players' profiles, it is also great when planning physical fitness programs throughout a season at all levels of competitions [21]. Also, describing anthropometric characteristics and body composition of basketball players and detecting possible differences in relation to competition levels may give coaches a better working knowledge of the studied groups, and can allow them to identify the factors that determine a player's potential to progress to higher levels of play.

\section{Conclusion}

The results of this study suggest that basketball players from both competitive levels had increased muscle and bone content in comparison to the control group (elite players significantly, sub-elite players slightly). It also suggests that basketball players from both competitive levels had decreased body fat in comparison to the control group (elite players significantly, sub-elite players slightly). The part attributed to the body height is the main cause of the talent identification process, while the differences in the body weight and BMI is logical consequence.

Since the body composition during the course of the season can be changed [35], the limitation of this study is that the testing was carried out in the middle of the competition season. Accordingly, in order to have an 
accurate insight into the changes during the macrocycle, the following tests should be planned at the beginning and at the end of the season. In this way we will surely get more precise data, which does not lessen the contribution of this preliminary study, because it also contains data that can help football experts to select talented players as best as possible.

\section{Conflicts of interest}

The authors declare no conflict of interest.

\section{References}

1. Vukasevic V, Spaic S, Masanovic B. Comparative study of anthropometric measurement and body composition between the basketball player first and second league in Montenegro. Journal of Anthropology of Sport and Physical Education. 2018; 2(3):61-65. https://doi.org/10.26773/jaspe.180711

2. Dogan I, Ersoz Y. The important game-related statistics for qualifying next rounds in Euroleague. Montenegrin Journal of Sports Science and Medicine. 2019; 8(1):43-50. https://doi.org/10.26773/mjssm.190307

3. Sporting Goods Manufacturers Association's. [Internet]. $U$. S. Trends in Team Sports. 2012 [cited 2012, September 6] Available from SFIA Sports \& Fitness Industry Association website: https://www.sfia.org/press/495_SGMA-ReportsThat-Team-Sports-in-the-U.S.-Are-Evolving.

4. Bankovic V, Dopsaj M, Terzic Z, Nesic G. Descriptive Body Composition Profile in Female Olympic Volleyball Medalists Defined Using Multichannel Bioimpedance Measurement: Rio 2016 Team Case Study. International Journal of Morphology. 2018; 36(2):699-708. https://doi.org/10.4067/S0717-95022018000200699

5. Scanlan A, Dascombe B, Reaburn P. A comparison of the activity demands of elite and sub-elite Australian men's basketball competition. Journal of Sports Sciences. 2011; 29(11):1153-1160. https://doi.org/10.1080/02640414.2011.582509

6. Arruda AFS, Aoki MS, Freitas CG, Drago G, Oliveira $\mathrm{R}$, Crewther BT, Moreira A. Influence of competition playing venue on the hormonal responses, state anxiety and perception of effort in elite basketball athletes. Physiology \& Behavior. 2014; 130:1-5. https://doi.org/10.1016/j.physbeh.2014.03.007

7. Masanovic B. Comparative Study of Morphological Characteristics and Body Composition between Different Team Players from Serbian Junior National League: Soccer, Handball, Basketball and Volleyball. International Journal of Morphology. 2019; 37(2):612- 619. https://doi.org/10.4067/S0717-95022019000200612

8. Popovic S, Bjelica D, Jaksic D, Hadzic R. Comparative Study of Anthropometric Measurement and Body Composition between Elite Soccer and Volleyball Players. International Journal of Morphology. 2014; 32(1):267- 274. https://doi.org/10.4067/S0717-95022014000100044

9. Yáñez-Sepúlveda R, Díaz-Barrientos S, MontielGonzález S, Zavala-Crichton JP. Características Antropométricas, Composición Corporal y Somatotipo en Tenistas ITF Elite Juniors Sudamericanos. International Journal of Morphology. 2018; 36(3):1095-1100. https://doi.org/10.4067/S0717-95022018000301095

10.Erčulj F, Štrumbelj E. Basketball Shot Types and Shot Success in Different Levels of Competitive Basketball. Plos One. 2015; 10(6):e0128885. https://doi.org/10.1371/journal.pone.0128885

11. Acar H, Tutkun E. Analysis of the 2D:4D ratios of national and amateur football players. International Journal of Applied Exercise Physiology. 2019; 8(1):132-137. https://doi.org/10.30472/ijaep.v8i1.326
12.Arifi F, Bjelica D, Masanovic B. Differences in anthropometric characteristics among junior soccer and handball players. Sport Mont. 2019; 17(1):45-49. https://doi.org/10.26773/smj.190208

13. Mooses M, Hackney AC. Anthropometrics and Body Composition in East African Runners: Potential Impact on Performance. International Journal of Sports Physiology and Performance. 2017;12(4):422-430 https://doi.org/10.1123/ijspp.2016-0408

14.Kolokoltsev MM. Ethnopedagogical component of physical training of schoolchildren. Obrazovanie I Nauka-Education and Science. 2017;19(3):156-170. https://doi.org/10.17853/1994-5639-2017-3-156-170

15.Bozic PR, Berjan Bacvarevic B. Force-velocity profiles of elite athletes tested on a cycle ergometer. Montenegrin Journal of Sports Science and Medicine. 2018; 7(1):59-66. https://doi.org/10.26773/mjssm.180308

16.Kukic F, Dopsaj M, Dawes J, Orr R, Cvorovic A. Use of Human Body Morphology as an Indication of Physical Fitness: Implications for Police Officers. International Journal of Morphology. 2018; 36(4):1407-1412. https://doi.org/10.4067/S0717-95022018000401407

17.Masanovic B, Corluka M, Milosevic Z. Comparative Study of Anthropometric Measurement and Body Composition of Junior Soccer and Handball Players from the Serbian National League. Kinesiologia Slovenica. 2018; 24(3):37- 46. https://doi.org/10.4067/S0717-95022019000200612

18.Gajardo-Burgos R, Barría-Vargas C, Flández-Valderrama J, Avendaño-Chipón R, Barría-Pailaquilén RM, Monrroy-Uarac M.PerfilAntropométrico de Basquetbolistas Sub-14 Chilenos. International Journal of Morphology. 2018; 36(3):943-947. https://doi.org/10.4067/S0717-95022018000300943

19.Le Gall F, Carling C, Williams M, Reilly, T. Anthropometric and fitness characteristics of international, professional and amateur male graduate soccer players from an elite youth academy. Journal of Science and Medicine in Sport. 2010; 13(1):90- 95. https://doi.org/10.1016/j.jsams.2008.07.004

20.Matiegka J. The testing of physical efficiency. American Journal of Physical Anthropology. 1921; 4:223- 230. https://doi.org/10.1002/ajpa.1330040302

21.Popovic S, Akpinar S, Jaksic D, Matic R, Bjelica D. Comparative Study ofAnthropometric MeasurementandBody Composition between Elite Soccer and Basketball Players. International Journal of Morphology. 2013; 31(2):461- 467. https://doi.org/10.4067/S0717-95022013000200016

22.Monson TA, Brasil MF, Hlusko LJ. Allometric variation in modern humans and the relationship between body proportions and elite athletic success. Journal of Anthropology of Sport and Physical Education. 2018; 2(3):3-8. https://doi.org/10.26773/jaspe.180701

23. Masanovic B. Comparative Study of Anthropometric Measurement and Body Composition between Junior Basketball and Volleyball Players from Serbian National League. Sport Mont, 2018;16:19-24. https://doi.org/10.26773/smj.181004

24.Torres-Unda J, Zarrazquin I, Gil J, Ruiz F, Irazusta A, Kortajarena M, Seco J, Irazusta J. Anthropometric, 
physiological and maturational characteristics in selected elite and non-elite male adolescent basketball players. Journal of Sports Sciences. 2013; 31(2):196-203. https://doi.org/10.1080/02640414.2012.725133

25.Bjelica D, Popovic S, Kezunovic M, Petkovic J, Jurak G, Grasgruber P. Body Height and Its Estimation Utilizing Arm Span Measurements in Montenegrin Adults. Anthropological Notebooks. 2012; 18(2):69-83.

26. Grasgruber P, Prce S, Stracarova N, Hrazdíra E, Cacek J, Popovic S, Hrebíckova S, Potpara P, Davidovic I, Kalina T. The coast of giants: an anthropometric survey of high schoolers on the Adriatic coast of Croatia. PeerJ. 2019; 7:e6598. https://doi.org/10.7717/peerj.6598

27. Olivier $\mathrm{PE}, \mathrm{Du}$ Toit $\mathrm{DE}$. Isokinetic neck strength profile of senior elite rugby union players. Journal of Science and Medicine in Sport. 2008; 11(2):96-105. https://doi.org/10.1016/j.jsams.2007.01.009

28.Hanson ED, Srivatsan SR, Agrawal S, Menon KS, Delmonico MJ, Wang MQ, Hurley BF. Effects of Strength Training on Physical Function: Influence of Power, Strength, and Body Composition. Journal of strength and conditioning research. 2009; 23(9):2627-2637. https://doi.org/10.1519/JSC.0b013e3181b2297b

29.Jeukendrup AE, Gleeson M. Sport Nutrition: An Introduction to Energy Production and Performance. Champaign, Human Kinetics; 2009.

30.Kerr D, Ackland T, Maslen B, Morton A, Prince R.
Resistance Training over 2 Years Increases Bone Mass in Calcium-Replete Postmenopausal Women. Journal of Bone and Mineral Research. 2001; 16(1):175- 181. https://doi.org/10.1359/jbmr.2001.16.1.175

31.Suominen H. Muscle training for bone strength. Aging Clinical and Experimental Research. 2006; 18(2):85- 93. https://doi.org/10.1007/BF03327422

32.Nikolaidis PT, Vassilios Karydis N. Physique and body composition in soccer players across adolescence. Asian Journal of Sports Medicine. 2011; 2(2):75- 82. https://doi.org/10.5812/asjsm.34782

33.Rostamian M, Bijeh N. The Effect of short-term aerobic exercise and green tea consumption on MFO, Fatmax, body composition and lipid profile in sedentary postmenopausal pomen. International Journal of Applied Exercise Physiology. 2017; 6(1):21-31. https://doi.org/10.22631/ijaep.v6il.100

34.Aslan A, Salci Y, Guvenc A. The effects of weekly recreational soccer intervention on the physical fitness level of sedentary young men. Montenegrin Journal of Sports Science and Medicine. 2019; 8(1):51-59. https://doi.org/10.26773/mjssm.190308

35.Astorino TA, Tam PA, Rietschel JC, Johnson SM, Freedman TP. Changes in Physical Fitness Parameters During a Competitive Field Hockey Season. Journal of Strength and Conditioning Research. 2004; 18(4):850-854. https://doi.org/10.1519/00124278-200411000-0002

\section{Information about the authors:}

Masanovic B. (Corresponding author); http://orcid.org/0000-0002-4939-4982; bojanma@ucg.ac.me; University of Montenegro; Narodne omladine bb, 81400 , Niksic, Montenegro.

Popovic S.; http://orcid.org/0000-0002-6633-3575; stevop@ucg.ac.me; University of Montenegro; Narodne omladine bb, 81400, Niksic, Montenegro.

Bjelica D.; http://orcid.org/0000-0001-5272-528X; dbjelica@ucg.ac.me; University of Montenegro; Narodne omladine bb, 81400, Niksic, Montenegro.

Cite this article as:

Masanovic B, Popovic S, Bjelica D. Comparative study of anthropometric measurement and body composition between basketball players from different competitive levels: elite and sub-elite. Pedagogics, psychology, medical-biological problems of physical training and sports, 2019;23(4):176-181.

https://doi.org/10.15561/18189172.2019.0403

This is an Open Access article distributed under the terms of the Creative Commons Attribution License, which permits unrestricted use, distribution, and reproduction in any medium, provided the original work is properly cited (http://creativecommons.org/licenses/by/4.0/deed.en).

Received: 08.05.2019

Accepted: 12.06.2019; Published: 29.08.2019 